\title{
NME1 wt Allele
}

National Cancer Institute

\section{Source}

National Cancer Institute. NME1 wt Allele. NCI Thesaurus. Code C52090.

Human NME1 wild-type allele is located in the vicinity of 17q21.3 and is approximately 9 $\mathrm{kb}$ in length. This allele, which encodes nucleoside diphosphate kinase A protein, is involved in the synthesis of three nucleoside triphosphates (CTP, GTP and UTP). A certain allelic variant of the NME1 gene is associated with advanced stage neuroblastoma. 